\title{
Seed germination and seedling morphology of Smilax polyantha (Smilacaceae)
}

\author{
Aline Redondo Martins ${ }^{1}$, Norbert Pütz ${ }^{2}$, Ana Dionisia da Luz Coelho Novembre ${ }^{3}$, \\ Sônia Maria de Stefano Piedade ${ }^{4}$ \& Beatriz Appezzato da Glória ${ }^{5,6}$ \\ ${ }^{1}$ Faculdade de Tecnologia de Capão Bonito, Rua Amantino de Oliveira Ramos, 60, \\ CEP 18300-000, Capão Bonito, SP, Brazil \\ ${ }^{2}$ Division of Biology and Education, University of Vechta, Driverstraße 22, 49377, Vechta, Germany \\ ${ }^{3}$ Departamento de Produção Vegetal, Escola Superior de Agricultura Luiz de Queiroz - ESALQ, \\ Universidade de São Paulo - USP, Av. Pádua Dias 11, CEP 13418-900, Piracicaba, SP, Brazil \\ ${ }^{4}$ Departamento de Ciências Exatas, Escola Superior de Agricultura Luiz de Queiroz - ESALQ, \\ Universidade de São Paulo - USP, Av. Pádua Dias 11, CEP 13418-900, Piracicaba, SP, Brazil \\ ${ }^{5}$ Departamento de Ciências Biológicas, Escola Superior de Agricultura Luiz de Queiroz - ESALQ, \\ Universidade de São Paulo - USP, Av. Pádua Dias 11, CEP 13418-900, Piracicaba, SP, Brazil \\ ${ }^{6}$ Corresponding author: Beatriz. Appezzato da Glória, e-mail: bagloria@esalq.usp.br
}

MARTINS, A.R., PÜTZ, N., NOVEMBRE, A.D.L.C., PIEDADE, S.M.S. \& APPEZZATO-DA-GLÓRIA, B. Seed germination and seedling morphology of Smilax polyantha (Smilacaceae). Biota Neotrop. 11(2): http:// www.biotaneotropica.org.br/v11n2/en/abstract?article+bn00411022011

\begin{abstract}
Brazilians have been using the underground organs of Smilax species in alternative medicine since the $19^{\text {th }}$ century because of their anti-rheumatic qualities. However, even nowadays, these species are explored only by extractivism. Studies on seed germination and development of these organs could be useful to preserve these plants. After germination, seedling development of Smilax polyantha was analyzed to understand underground stem formation. Furthermore, to analyze the ontogenesis of the underground system, seedlings aged from one to twelve months were sectioned. One of the most striking features of this species is the presence of two stem branching systems. The plumule gives rise to the first stem branching system with negative geotropism. Its first underground axillary bud sprouted into the other caulinar axis with positive geotropism. The horizontal growth and the subsequent thickening of this underground organ depended on the development of axillary buds from basal nodes of the previous branches. The cotyledonary bud did not play a role in the underground formation, as previously described in the literature for this genus, but the buds of the basal cataphylls built the second stem branching system. In this study we discuss the terminology and suggest calling this second stem branching system a rhizophore.
\end{abstract}

Keywords: anatomy, development, greenbrier, rhizome, rhizophores.

MARTINS, A.R., PÜTZ, N., NOVEMBRE, A.D.L.C., PIEDADE, S.M.S. \& APPEZZATO-DA-GLÓRIA, B. Germinação e morfologia de plântulas de Smilax polyantha (Smilacaceae). Biota Neotrop. 11(2): http://www. biotaneotropica.org.br/v11n2/pt/abstract?article+bn00411022011

Resumo: As espécies de Smilax L. são utilizadas na medicina popular brasileira desde o século 19 devido às propriedades anti-reumáticas atribuídas aos órgãos subterrâneos de todas as espécies. No entanto, ainda hoje, essas espécies são exploradas apenas por extrativismo. Estudos sobre a germinação e o desenvolvimento dos órgãos subterrâneos podem ser úteis para preservar essas plantas. Após a germinação, o desenvolvimento de plântulas de Smilax polyantha foi analisado para compreender a formação do sistema subterrâneo. Para a análise da ontogênese do sistema subterrâneo foram seccionadas plantas em diferentes estágios de desenvolvimento entre um e doze meses. Uma das características mais marcantes desta espécie é a presença de dois sistemas de ramificação caulinar. A plúmula dá origem ao primeiro sistema caulinar de ramificações com geotropismo negativo. As gemas axilares subterrâneas desse primeiro eixo caulinar originam o segundo eixo caulinar com geotropismo positivo. $\mathrm{O}$ crescimento horizontal e o espessamento do órgão subterrâneo dependem do desenvolvimento de gemas axilares de nós basais dos ramos anteriores. A gema cotiledonar não participa da formação do caule subterrâneo, como descrito anteriormente na literatura para este gênero, mas as gemas axilares basais dos ramos caulinares aéreos originam o segundo eixo de ramificação caulinar subterrâneo. Neste estudo, após ser discutida a terminologia mais adequada, sugere-se chamar o caule subterrâneo dessas espécies de rizóforo.

Palavras-chave: anatomia, desenvolvimento, salsaparrilha, rizoma, rizóforos. 


\section{Introduction}

The Smilax genus consists of approximately 30 species widely distributed across the Brazilian territory. Plants are known as "salsaparrilha" and "japecanga" in the Brazilian popular medicine. However, even nowadays, these species are explored only by extractivism.

Studies on seed germination are important to solve taxonomic and phylogenetic problems, to contribute to the knowledge of plant morphology through the ontogenesis, to recognize species in the field. Moreover, these studies reinforce the necessity of conservation of Smilax species in forest and tropical savanna (Cerrado) areas of Brazilian central region (Andreata \& Pereira 1990).

Several authors investigated the germination and development of Smilax species (Holm 1890, Andreata 1980, Pogge \& Bearce 1989, Andreata \& Pereira 1990, Andreata \& Menezes 1999, Rosa \& Ferreira 1999, D'Antuono \& Lovato 2003, Santos et al. 2003). However, there are conflicting results on the seed germination rates.

Holm (1890) extensively investigated and described the development of the underground systems of some North American species of Smilax without anatomical data. Andreata \& Pereira (1990) described the post-seminal development as divided into seedling and young plant stages. According to the authors, the seedlings were characterized by the presence of eophyll and the young plants by the presence of protophylls. Andreata \& Menezes (1999) described the underground system in Smilax quinquenervia using both morphological and anatomical features, defining this system as rhizophores based on its origin.

This study presents seed germination and seedling and young plant morphology of Smilax polyantha Grisebach and discusses the terminology of the underground system.

\section{Material and methods}

\section{Plant Material}

Seedlings were obtained by germination studies from seeds of Smilax polyantha Grisebach collected from several adult plants in Pratânia-SP (S $22^{\circ} 48^{\prime}$ 54, 5' 'W 48 44' 33,2' ') and Mogi Guaçu, SP (S $22^{\circ} 15^{\prime} 18,9^{\prime}$ ' $\mathrm{W} 47^{\circ} 9^{\prime} 15,7^{\prime}$ '), in Cerrado areas in southeastern Brazil, during April and May of 2006. The voucher of the specimen (107664) was deposited in the ESA Herbarium, Brazil. Seedlings were cultivated in greenhouse during one year after germination.

\section{Germination study}

The experiment was conducted in a completely randomized design with six different treatments $\left(15-35{ }^{\circ} \mathrm{C}, 20-30{ }^{\circ} \mathrm{C}, 20-35{ }^{\circ} \mathrm{C}\right.$, $20^{\circ} \mathrm{C}, 25^{\circ} \mathrm{C}$ and $30^{\circ} \mathrm{C}$ ) and eight replications. All treatments were exposed to a daily photoperiod of eight hours. For each replication, a germination box $(11 \times 11 \times 3 \mathrm{~cm})$ with cover was used, where $292 \mathrm{~g}$ of sand was added, containing $45 \mathrm{~mL}$ of water $(60 \%$ of the restrained value) with 25 seeds.

The experiment was established in October 2006 and finished in November 2007. The seeds in which a normal-appearing embryo was observed were submitted to tetrazolium test (Brasil 1992) to determine their viability. In that test, immediately following the longitudinal section, the seeds were placed into a small plastic cup containing $1 \%$ tetrazolium. This container was covered with aluminum sheet to prevent the evaporation of the solution and kept at $30^{\circ} \mathrm{C}$ for 24 hours. The seeds with red-colored embryo were considered viable.

Analyses of variance were performed (one factor: treatment), using Tukey's test in order to identify possible differences between number of germinated seeds among treatments $(\mathrm{p} \leq 0.05)$.

\section{Morphology and anatomy}

The observation of seedlings and young plants development was performed from December 2006, when the first seedlings were obtained, to December 2007. The definition and differentiation of seedlings and young plants were based on Smilax studies by Andreata \& Pereira (1990).

Seedlings and young plants at different stages were fixed in Karnovsky solution (Karnovsky 1965), dehydrated in ethanol series and stored in $70 \%$ ethanol. The morphology of the vegetative organs was registered through photographs and botanical illustrations. The morphology of the seedlings was described according to Tillich (2007).

For the anatomical analysis, samples from different developmental stages of Smilax polyantha were fixed as above described, dehydrated in ethylic series and embedded in historesin (Leica Historesin). Serial sections were cut at 8-10 $\mu \mathrm{m}$ thickness on a rotary microtome (Sass 1951) and stained with toluidine blue O (Sakai 1973). Permanent slides were mounted in synthetic resin "Entellan". Images from slides were captured digitally through a Leica DMLB microscope with a video camera attached to a PC, using Leica, IM50 image analysis software.

\section{Results}

\section{Germination study}

The highest number of germinated seeds was found at $30^{\circ} \mathrm{C}$, followed by $20-30{ }^{\circ} \mathrm{C}$ (Table 1 ). Rates of germination for both treatments were $27 \%$ and $14.5 \%$, respectively (Table 1). By analyzing the viability of seed with tetrazolium test (Table 1), it was possible to verify that $86 \%$ of the seeds continued to be viable in the treatment $20{ }^{\circ} \mathrm{C}$ and $50 \%$ in the treatment $30^{\circ} \mathrm{C}$. Seeds which were considered to be viable had an embryo with reddish colour after the immersion in tetrazolium solution. Non-viable seeds were those with destroyed embryo (by fungi) or with no reddish colour after the test. Few seeds were found with no embryo (not viable seeds), as well as viable seeds with two embryos.

Although there is no significant difference between the temperatures $30{ }^{\circ} \mathrm{C}$ and $20-30{ }^{\circ} \mathrm{C}$ (Table 2), the percentage values suggest that temperature $30^{\circ} \mathrm{C}$ should be used for seed germination of the studied species. The other four treatments showed a low number of germinated seeds, with rates of germination below $5 \%(1.0 \%, 4.0 \%$, $2.5 \%$ and $3.5 \%$ for $20^{\circ} \mathrm{C}, 25^{\circ} \mathrm{C}, 15-35^{\circ} \mathrm{C}$ and $20-30{ }^{\circ} \mathrm{C}$, respectively).

Several other factors were analyzed for seed germination under $30^{\circ} \mathrm{C}$ but none of them improved their rates of germination (data not shown). As seeds were viable and presented satisfactory absorption

Table 1. Seed viability of Smilax polyantha after tetrazolium test at the end of seed germination experiment. (V) Number of seeds not germinated, but still viable; (NV) Number of seeds not germinated and not viable; percentage of seed germination $(\mathrm{G} \%)$.

Tabela 1. Viabilidade das sementes de Smilax polyantha após o teste do Tetrazólio ao final do experimento de germinação de sementes. (V) Número de sementes não germinadas, mas ainda viáveis; (NV) Número de sementes não germinadas e não viáveis; Porcentagem de germinação de sementes (G \%).

\begin{tabular}{|c|c|c|c|c|c|c|c|c|c|c|c|c|}
\hline & \multicolumn{2}{|c|}{$20{ }^{\circ} \mathrm{C}$} & \multicolumn{2}{|c|}{$25^{\circ} \mathrm{C}$} & \multicolumn{2}{|c|}{$30{ }^{\circ} \mathrm{C}$} & \multicolumn{2}{|c|}{$15-35{ }^{\circ} \mathrm{C}$} & \multicolumn{2}{|c|}{ 20-30 ${ }^{\circ} \mathrm{C}$} & \multicolumn{2}{|c|}{$20-35{ }^{\circ} \mathrm{C}$} \\
\hline & $\mathbf{V}$ & NV & $\mathbf{V}$ & NV & $\mathbf{V}$ & NV & $\mathbf{V}$ & NV & $\mathbf{V}$ & NV & $\mathbf{V}$ & $\mathbf{N V}$ \\
\hline Number of seeds & 172 & 26 & 160 & 32 & 100 & 46 & 164 & 31 & 145 & 26 & 166 & 27 \\
\hline Seeds germinated & \multicolumn{2}{|c|}{2} & \multicolumn{2}{|c|}{8} & \multicolumn{2}{|c|}{54} & \multicolumn{2}{|c|}{5} & \multicolumn{2}{|c|}{29} & \multicolumn{2}{|c|}{7} \\
\hline $\mathrm{G} \%$ & \multicolumn{2}{|c|}{1.0} & \multicolumn{2}{|c|}{4.0} & \multicolumn{2}{|c|}{27.0} & \multicolumn{2}{|c|}{2.5} & \multicolumn{2}{|c|}{14.5} & \multicolumn{2}{|c|}{3.5} \\
\hline
\end{tabular}


of water, it is possible that the low germination percentage of this species might be associated with the seed metabolism.

\section{Morphology and anatomy of seedlings}

The germination of this species was cryptohypogeal (Figure 1a). At the beginning of germination, the cotyledonary sheath, plumule, hypocotyl and radicle are pushed through the testa on the opposite side of the hilum (Figures 1, 2a).

The cotyledon was compact and consisted of a haustorial hyperphyll and a short cotyledonary sheath embracing the cotyledonary node and protecting the plumule axis (Figure 1b). The cotyledonary sheath exhibited idioblasts with raphides.
Both hypocotyl and epicotyl were very short $(480 \mu \mathrm{m}$ and $200 \mu \mathrm{m}$ in length, respectively) and the first plumular leaf and the first axillary bud were basally embraced by the cotyledonary sheath (Figure 2a).

In transection, the hypocotyl was composed by a uniseriated epidermis with stomata, the cortex was parenchymatous and a few cells of its innermost layer (endodermis) exhibited U-shaped thickenings. The vascular cylinder was a transition zone where it was not possible to analyze the maturation of the protoxylem strands and the arrangement of xylematic and phloematic elements (Figure 1c). The primary root showed uniseriate epidermis, cortex with isodiametrical cells, idioblasts with raphides, endodermis with thick-walled cells and a vascular cylinder - tetrarch and protostelic - surrounded by a uniseriated pericycle with thin-walled cells (Figure 1d).
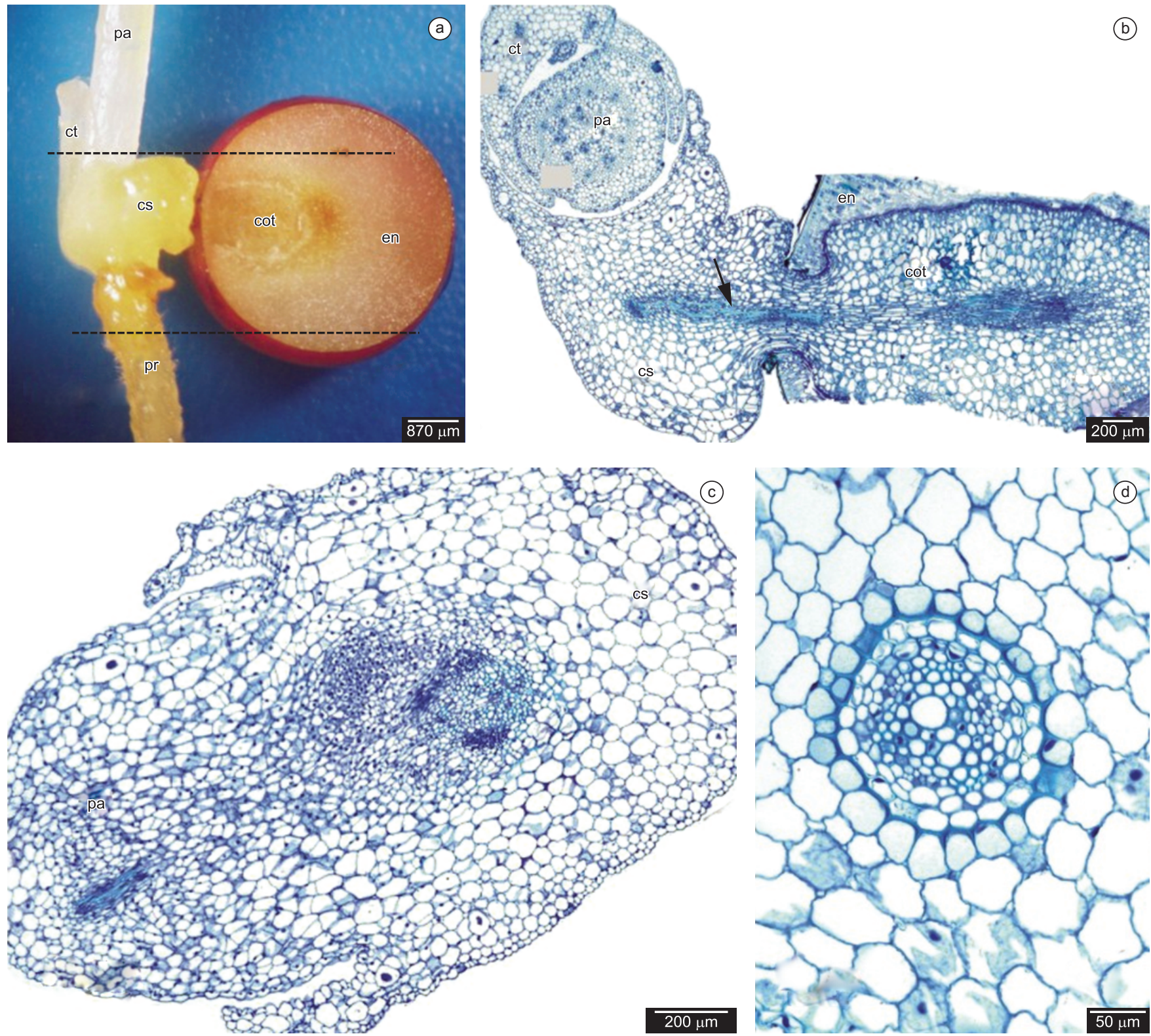

Figure 1. a) Seedling of Smilax polyantha with few days after germination. Dotted lines indicate the cross sectioned sector showed from b to d. b) Cotyledon consisting of a haustorial hyperphyll (cot) and a short cotyledonary sheath (cs) protecting the plumular axis (pa). c) Vascular transition region below of the insertion of the cotyledon and the cotyledonary sheath. $\mathrm{d}$ ) Primary root. $\mathrm{cs}=$ cotyledonary sheath; $\mathrm{cot}=$ cotyledon; $\mathrm{ct}=$ cataphyll; en $=\mathrm{endosperm}$; pa $=$ plumular axis; $\mathrm{pr}=$ primary root; arrow $=$ vascular tissue.

Figura 1. a) Plântula de Smilax polyantha poucos dias após a germinação. As linhas pontilhadas indicam a região seccionada apresentada em b a d. b) O cotilédone é haustorial (cot) e a bainha cotiledonar é curta (cs) protegendo o eixo caulinar plumular (pa). c) Região de transição vascular abaixo da inserção dos cotilédones e da bainha cotiledonar. d) Raiz primária. cs = bainha cotiledonar; cot = cotilédone; ct = catafilo; en = endosperma; pa = eixo caulinar plumular; $\mathrm{pr}=$ raiz primária; arrow $=$ tecido vascular. 
The plumule of these seedlings gave rise to at least three cataphylls before foliage leaves (eophylls) were produced. The cataphylls were hyaline, apiculate, one on each node, alternate and amplexicaul. They showed three collateral vascular bundles and stomata were observed in the epidermis of the cataphyll and cotyledonary sheath.

Serial longitudinal (Figure 2a) and cross sections (Figure 2b, c) of different seedlings allowed us to verify that the cotyledonary bud did not play a role in the rhizophore formation. There was a meristematic area that corresponded to a rudimentary cotyledonary bud at the insertion point of the cotyledonary sheath with the cotyledon (Figure 2c).

Following the development of the seedling from one month to one year of age (Figure 3), it was possible to verify that the primary root was not short-lived as in other monocotyledons, whereas it did not have a conspicuous growth.

One-month-old seedlings had the primary root and white adventitious roots, plumular axis with two cataphylls and the seed was still attached to the seedling (Figure 3a, c).

Five-month-old seedlings contained three visible hyaline cataphylls, the eophyll, the first metaphyll and its first stem

Table 2. Analysis of variance of the number of germinated seeds of Smilax polyantha. Data were transformed into the square root of $(x+0.5)$ to reduce variation. Values of $\mathrm{F}$ and the coefficient of variation $(\mathrm{CV})$. Different letters mean significant differences between treatments (Tukey's test, $\mathrm{p} \leq 0.05$ ).

Tabela 2. Análise de variância do número de sementes germinadas de Smilax polyantha. Os dados foram transformados na raiz quadrada de $(\mathrm{x}+0.5)$ para reduzir a variação. Valores de F e do coeficiente de variação (CV). Letras diferentes representam diferenças significativas entre os tratamentos (Teste de Tukey, $\mathrm{p} \leq 0.05)$.

\begin{tabular}{cc}
\hline Treatments & Germinated seeds \\
\hline $20{ }^{\circ} \mathrm{C}$ & $0.8365^{\mathrm{b}}$ \\
$25^{\circ} \mathrm{C}$ & $1.1358^{\mathrm{b}}$ \\
$30^{\circ} \mathrm{C}$ & $2.5833^{\mathrm{a}}$ \\
$15-35^{\circ} \mathrm{C}$ & $1.0105^{\mathrm{b}}$ \\
$20-30{ }^{\circ} \mathrm{C}$ & $1.9760^{\mathrm{a}}$ \\
$20-35^{\circ} \mathrm{C}$ & $1.1197^{\mathrm{b}}$ \\
$\mathrm{CV}(\%)$ & 34.2324 \\
$\mathrm{~F}$ (treatments) & $15.32^{* * *}$ \\
\hline
\end{tabular}

$* * * \mathrm{p} \leq 0.001$ ramification. The basis of the two-caulinar branches started to enlarge (Figure 3d, e), but some parts of the seed remained attached.

One-year-plants had three aerial branches (Figures 3f, 4a). The primary root was still present but it was very difficult to distinguish it from the adventitious roots in different developmental stages from the basal region of the stem branches (Figure 3f). The anatomical analysis of the enlarged caulinar basis (Figure 4b) showed that the horizontal growth and the subsequent thickening of the underground organ depended on the axillary buds development from basal nodes of the previous branches.

\section{Discussion}

Holm (1890) was the first author to describe the morphology of the underground stem of Smilax rotundifolia and S. glauca, which are common species in North America. According to Holm (1890), the thickened region of the underground system of Smilax rotundifolia is called rhizome, and its origin is in the axillary bud of the cotyledon. Andreata \& Menezes (1999) also described the formation of the underground stem in Smilax quinquenervia from the cotyledonary bud. However, in S. polyantha the cotyledonary bud is rudimentary and the origin of the underground stem is from the axillary bud of the first cataphyll at the plumular axis.

Underground stems as the ones of the genus Smilax are used to be called 'rhizome' (Holm 1890, Arber 1925, Raunkiaer 1934, Troll 1937, Holttum 1955). Troll (1937) defined rhizomes as underground stems, growing under the surface of the soil, with internodes and nodes, with cataphylls, their axillary buds and, of course, with adventitious roots. Their main feature is a thick structure, which is necessary to store nutrients. Several papers dealt with this definition and gave detailed information about the rhizomes of different species (Troll 1937, Bell \& Tomlinson 1980, Pütz \& Sukkau 2002).

Andreata \& Menezes (1999) described the underground stem of the Smilax quinquenervia as rhizophore. Rhizophores are the second vegetative stem branching system in plants whose plumule gives rise to the aerial vegetative branching system. The great difference between rhizome and rhizophore is that rhizome originates from the plumule (Holm 1929, Troll 1937) and constitutes the only vegetative stem branching system of the plant. Rhizophore arises from the cotyledonary bud (Andreata \& Menezes 1999; Hayashi \&Appezzato-da-Glória 2005), from the thickening of the hypocotyl
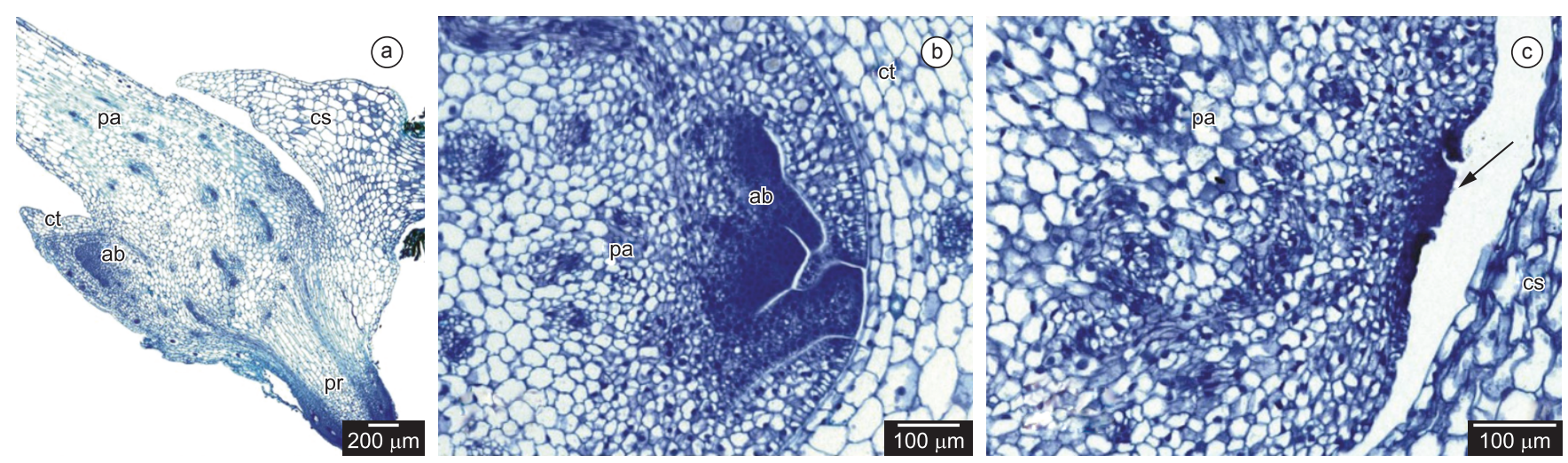

Figure 2. a) Longitudinal and b,c) cross sections of seedlings of Smilax polyantha a few days after germination at a similar sector indicated in a. Notice the short epicotyl and a rudimentary cotiledonary bud (Figure c, arrow). The first axillary bud of the cataphyll (ct) is seen in detail in a and b. ab = axillary bud; $\mathrm{cs}=$ cotyledonary sheath; $\mathrm{ct}=$ cataphyll; $\mathrm{pa}=$ plumular axis; $\mathrm{pr}=$ primary root.

Figura 2. a) Secções longitudinal e b,c) transversais de plantas de Smilax polyantha poucos dias após a germinação na região indicada em a. Detalhe do epicótilo curto e gema axilar rudimentar (Figura c, seta). A primeira gema axilar (ct) é visualisada em detalhe em a e b. ab = gema axilar; cs = bainha cotiledonar; ct $=$ catafilo; $\mathrm{pa}=$ eixo caulinar plumular; $\mathrm{pr}=$ raiz primária. 

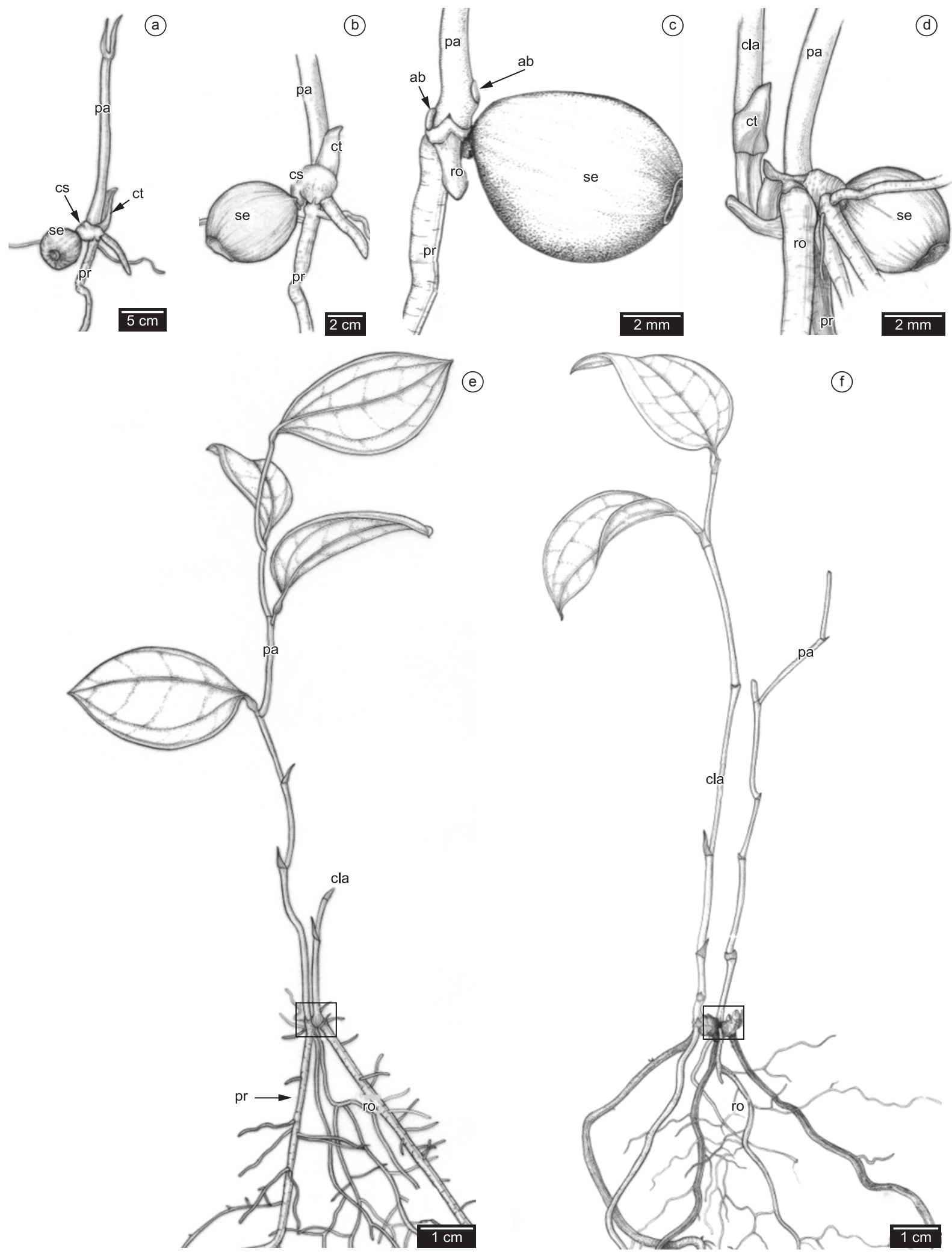

Figure 3. Seedlings and one-year-old plant of Smilax polyantha. a,c) One-month-old seedlings. c) Two axillary buds are indicated after removing the cataphyll. d) The detail of the underground stem indicated in E. e) Five-month-old seedling. f) One-year-old plant. The sector indicated in E is shown in Figure 4. ab = axillary bud; cla $=$ caulinar axis from axillary bud development; $\mathrm{cs}=$ cotyledonary sheath; $\mathrm{ct}=$ cataphyll, $\mathrm{pa}=$ caulinar axis from plumular development; $\mathrm{pr}=$ primary root; ro = adventitious roots; se $=$ seed.

Figura 3. Plantas jovens e plantas com um ano de idade de Smilax polyantha. a,c) Plantas com um mês de desenvolvimento. c) A remoção dos catafilos evidencia as duas gemas axilares. d) Detalhe do caule subterrâneo indicado em E. e. Planta com cinco meses de desenvolvimento. f) Planta com um ano de idade. A região indicada em E está em detalhe na Figura 4. ab = gema axilar; cla = eixo caulinar originado pelo desenvolvimento de uma gema axilar subterrânea; cs = bainha cotiledonar; $\mathrm{ct}=$ catafilo, $\mathrm{pa}=$ eixo caulinar desenvolvido pela plúmula; $\mathrm{pr}=$ raiz primária; ro = raiz adventícia; $\mathrm{se}=$ semente . 

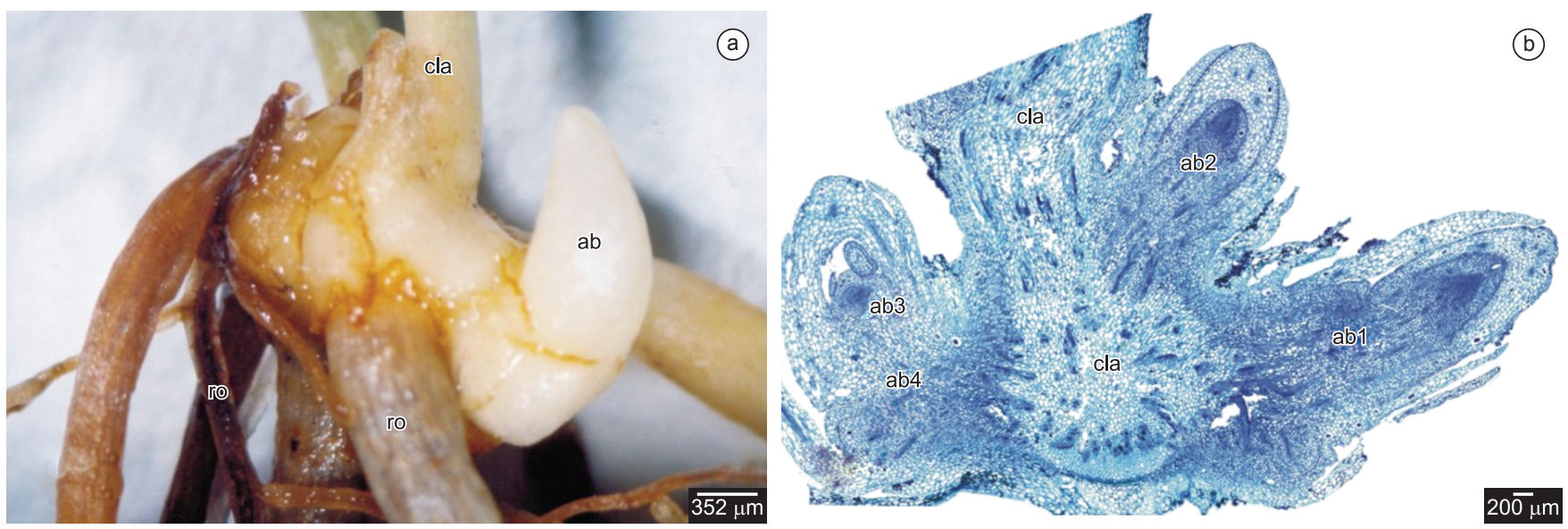

Figure 4. a,b) Rhizophore of Smilax polyantha. b) Longitudinal section. There are two caulinar axis (cla) and four buds. Note the horizontal growth and the subsequent thickening of the underground organ depend on the axillary buds $(\mathrm{ab})$ development from basal nodes of the previous branches. ro $=$ roots.

Figura 4. a,b) Rizóforo de Smilax polyantha. b) Secção longitudinal. Dois eixos caulinares (cla) e quatro gemas axilares. Detalhe do crescimento e do espessamento do caule subterrâneo dependente das gemas axilares (ab) que se desenvolvem de nós basais de ramos caulinares pré-existentes. ro = raízes.

(Menezes 2006) or from the first axillary bud of the plumular axis as described in S. polyantha.

As important as the adequate use of the terminology and the description of the morphology is the necessity of discussing the strategy of survival of this species in the Cerrado environment. According to Pütz (2006), we cannot consider the underground systems to be static. Rhizophores as found in $S$. polyantha and rhizomes are dynamic systems that fulfill some survival aspects, such as occupancy sites, clonal growth and vegetative dispersal.

Smilax polyantha had low rates of germination (27\%) compared to Smilax campestris (Rosa and Ferreira, 1999), S. glauca and S. rotundifolia (Pogge \& Bearce 1989). Rosa \& Ferreira (1999) observed $71 \%$ of germinated seeds under constant $30{ }^{\circ} \mathrm{C}$ and continuous light and $51 \%$ under alternate temperatures of $25 / 35^{\circ} \mathrm{C}$, while Pogge \& Bearce (1989) found rates of $95 \%$ for $S$. rotundifolia and $82 \%$ for Smilax glauca under constant $22{ }^{\circ} \mathrm{C}$.

Considering the Cerrado environment (high temperatures and radiation levels and unfertile sandy soil), where $S$. polyantha can be found, we believe that the low germination percentage of this species is not only related to temperature and light for germination of seeds, as tested by the above cited authors. Since a high number of seeds were still viable after one year of experiment some seed intrinsic factors might be responsible for the delay of germination enhancing viability of the seeds as reported by Baskin \& Baskin (2001) for Smilax glauca and $S$. rotundifolia.

According to Andreata (1980), the beginning of germination can vary between 39 and 93 days for the seeds of Smilax rufescens, S. elastica, S. syphylitica, S. quinquenervia and S. syringoides. S. polyantha took at least 62 days. Rosa \& Ferreira (1999) viewed the beginning of germination after 30 days to $S$. campestris and Pogge \& Bearce (1989) only obtained 50\% of seed germination after 60 days to $S$. glauca and $S$. rotundifolia.

The delay at the beginning of germination in Smilax was already considered as a period of dormancy of the seed (Santos et al. 2003). However, $S$. polyantha seeds did not have difficulties in absorbing water.

Although $S$. polyantha has a low rate of germination, at the beginning of the seedling development these plants already have axillary buds in the underground stem that allow them to survive and to sprout after fire, a common disturbance event in Cerrado ecosystems (Coutinho 1982, Hoffmann 1998, Medeiros \& Miranda
2008). On the other hand, this type of strategy assures a successful establishment and thus, survival in the environment. The presence of underground axillary buds and the capacity of sprouting should be examined under ecological point of view of clonal growth (compare Klimeš et al. 1997).

Regarding the efforts of conservation biologists in protecting species from the Cerrado, we could consider $S$. polyantha as a threatened species, mainly because of the extractivism activity. On one hand, this species showed low rates of germination and very slow development. On the other hand, the part used in the popular medicine is the underground system. Hence, extractivism activities hinder sprouting and may therefore be a great threat to the protection of this species in Cerrado ecosystems.

\section{Conclusion}

The morphological and anatomical analyses confirm that the underground system of Smilax polyantha is a rhizophore since it constitutes a second cauline system in the plant. Its origin is from the axillary bud of the first cataphyll at the plumular axis and not from cotyledonary buds as previously reported for other Smilax species.

\section{Acknowledgements}

We thank to FAPESP (São Paulo Council for Research) - BIOTA Program (Project Proc. $n^{\circ}$ 05/54984-5 and Proc. $n^{\circ}$ 05/58964-9), for the financial support. We also thank the technical laboratory support of Marli K. M. Soares and Helena P. Chamma. We are thankful to Wiebeke Bruhn, Stefanie Theler, Frauke Müller and Alessandra Fidelis for the English review. We also thank the coordinator of the Reserva Biológica e Estação Experimental de Mogi Guaçu, Instituto de Botânica and the owners of the Fazenda Palmeira da Serra, Pratânia-SP, for giving permission to collect plant material for this study.

\section{References}

ANDREATA, R.H.P. 1980. Smilax Linnaeus (Smilacaceae): Ensaio para uma revisão das espécies brasileiras. Arq. Jard. Bot. Rio J. 24:179-301.

ANDREATA, R.H.P. \& MENEZES, N.L. 1999. Morfoanatomia do embrião, desenvolvimento pós-seminal e origem do rizóforo de Smilax quinquenervia Vell. Bol. Bot. Univ. São Paulo 18:39-51. 
ANDREATA, R.H.P. \& PEREIRA, T.S. 1990. Morfologia das plântulas de algumas espécies de Smilax L. Pesqui. Bot. 41:7-24.

ARBER, A. 1925. Monocotyledons: a morphological study. Cambridge University Press, Cambridge.

BASKIN, C.C. \& BASKIN, J.M. 2001. Seeds: Ecology, Biogeography, and Evolution of Dormancy and Germination. Academic Press, San Diego, Califórnia

BELL, A.D. \& TOMLINSON, P. B. 1980. Adaptive architecture in rhizomatous plants. Bot. J. Linn. Soc. 80:125-160. http://dx.doi. org/10.1111/j.1095-8339.1980.tb01662.x

BRASIL. Ministério da Agricultura e Reforma Agrária. 1992. Regras para Análise de Sementes. SNAD-DNDV- CLAV, Brasília.

COUTINHO, L.M. 1982. Ecological effects of fire in Brazilian Cerrado. In Ecology of tropical savannas (B. J. Huntley \& B. H. Walker, eds). Springer Verlag, Berlin, p. 273-291.

D'ANTUONO, L.F. \& LOVATO, A. 2003. Germination trials and domestication potential of three native species with edible sprouts: Ruscus aculeatus L., Tamus communis L. and Smilax aspera L. Acta Hortic. 598:211-218.

HAYASHI, A.H., APPEZZATO-DA-GLÓRIA, B. 2005. The origin and anatomy of rhizophores in Vernonia herbacea and $V$. platensis (Asteraceae) from the Brazilian Cerrado. Aust. J. Bot. 53:273-279. http:// dx.doi.org/10.1071/BT04094

HOFFMANN, W.A. 1998. Post-burn reproduction of woody plants in a neotropical savanna: the relative importance of sexual and vegetative reproduction. J. Appl. Ecol. 35:422-433. http://dx.doi.org/10.1046/j.13652664.1998.00321.x

HOLM, T. 1890. Contributions to the knowledge of the germination of some North American plants. Mem. Torr. Bot. Club 2:57-108.

HOLM, T.1929. The application of the term "rhizome". Rhodora 361:6-20.

HOLTTUM, R.E. 1955. Growth-habits of monocotyledons - variations on a theme. Phytomorphology 5:399-413.

KARNOVSKY, M.J. 1965. A formaldehyde-glutaraldehyde fixative of high osmolality for use in electron microscopy. J. Cell Biol. 27:137-138.

KLIMEŠ, L., KLIMEŠOVÁ, J., HENDRIKS, R. \& GROENENDAEL, J. van. 1997. Clonal plant architecture: a comparative analysis of form and function. In The ecology and evolution of clonal plants (H. Kroon \& J. van. Groenendael, eds). Backhuys Publishers, Leiden, p. 1-29.

MEDEIROS, M.B. \& MIRANDA, H.S. 2008. Post-fire resprouting and mortality in cerrado woody plant species over a three-year period. Edinb. J. Bot. 65:53-68. http://dx.doi.org/10.1017/S0960428608004708

MENEZES, N.L. 2006. Rhizophores in Rhizophora mangle L: an alternative interpretation of so-called 'aerial roots". An. Acad. Bras. Ciênc. 78:213226. http://dx.doi.org/10.1590/S0001-37652006000200003

POGGE, F.L. \& BEARCE, B.C. 1989. Germinating Common and Cat Greenbrier. Tree Planters' Notes 40:34-37.

PÜTZ, N. 2006. Seedling establishment, underground kinetics, and clonal reiteration: How do Potentilla inclinata and Inula ensifolia get their multifunctional subterranean systems? Flora 201:298-306.

PÜTZ, N. \& SUKKAU, I. 2002. Seedling establishment, bud movement, and subterranean diversity of subterranean systems in Apiaceae. Flora 197:385-393.

RAUNKIAER, C. 1934. The life form of plants and statistical plant geography. Clarendon Press, Oxford.

ROSA, S.G.T. \& FERREIRA, A.G. 1999. Germination of medicinal plant: Smilax campestris Griseb. (salsaparrilha). Acta Hortic. 502:105-111.

SAKAI, W.S. 1973. Simple method for differential staining of paraffin embedded plant material using toluidine blue O. Stain Tech. 48:247-249.

SANTOS, M.R.A., PAIVA, R., GOMES, G.A.C, PAIVA, P.D.O. \& PAIVA, L.V. 2003. Estudos sobre superação de dormência em sementes de Smilax japecanga Grisebach. Ciênc. Agrotec. Lavras 27:319-324.

SASS, J.E. 1951. Botanical microtechnique. Iowa State University Press, Ames.

TILLICH, H.J. 2007. Seedling diversity and the homologies of seedlings organs in the order Poales (Monocotyledons). Ann. Bot. 100:14131429. PMid:17933843. PMCid:2759217. http://dx.doi.org/10.1093/ $\mathrm{aob} / \mathrm{mcm} 238$

TROLL, W. 1937. Vergleichende Morphologie der höheren Pflanzen, 1.Vegetationsorgane. Borntraeger, Berlin. 